\title{
THE CONVENTIONAL METHOD OF RAINWATER COLLECTION AND THE ION-EXCHANGE RESIN METHOD IN MONITORING THE NITROGEN DEPOSITION FROM THROUGH FALL
}

\author{
WANG, G. ${ }^{1}-$ HAN, L. $^{2 *}-$ TANG, X. Y. ${ }^{1}-$ YANG, Y. ${ }^{2}$ \\ ${ }^{1}$ Institute of Plateau Meteorology, China Meteorological Administration /Heavy Rain and \\ Drought - Flood Disasters in Plateau and Basin Key Laboratory of Sichuan Province, Chengdu \\ 610072, China
}

${ }^{2}$ Chengdu University of Information Technology, Chengdu 610225, China

*Corresponding author

e-mail: hanlin@cuit.edu.cn

(Received 22 ${ }^{\text {nd }}$ Apr 2019; accepted 11 $1^{\text {th }}$ Jul 2019)

\begin{abstract}
Concerns are on the rise over the impact of atmospheric nitrogen $(\mathrm{N})$ deposition on forest ecosystems in the tropical and subtropical areas. This study used the conventional rainwater collection method and the ion-exchange resin (IER) method to measure through fall $\mathrm{N}$ deposition over time in the Picea abies forests in the Tibet Plateau. The results were compared, and their applicability in determining the atmospheric $\mathrm{N}$ deposition was analyzed. The results indicated a strong correlation between the IER method and the conventional method in determining the $\mathrm{NH}_{4}{ }^{+}-\mathrm{N}$ and $\mathrm{NO}_{3}{ }^{-} \mathrm{N}$ content $\left(\mathrm{R}^{2}=0.47\right.$ and $\left.\mathrm{R}^{2}=0.75, P<0.001\right)$. However, the $\mathrm{NH}_{4}{ }^{+}-\mathrm{N}$ content measured with the IER method was generally lower, while the $\mathrm{NO}_{3}-\mathrm{N}$ was generally higher. The total mineral $\mathrm{N}$ deposition in through fall measured with both methods was about the same. Therefore, we can use the IER method instead of the conventional method for determining the total inorganic $\mathrm{N}$ deposition in forests at the Tibet Plateau.
\end{abstract}

Keywords: Tibet Plateau, forest ecosystems, atmospheric nitrogen deposition, $\mathrm{NH}_{4}{ }^{+}-\mathrm{N}$ content, $\mathrm{NO}_{3}{ }^{-} \mathrm{N}$ content

\section{Introduction}

From 1860 to 2000, the nitrogen $(\mathrm{N})$ discharged into the atmosphere had increased from $15 \mathrm{Tg} \mathrm{N}^{-1}$ to $165 \mathrm{Tg} \mathrm{N} \mathrm{a}^{-1}$ due to human activities (Chen, 2007). Rainwater penetration is an important factor that keeps the nutrient balance of forest ecosystems, directly affecting the distribution of soil moisture and recycling of nutrients (CarlyMoses, 2004). Therefore, a quantitative assessment of $\mathrm{N}$ sediment in penetration rainwater is key in monitoring atmospheric $\mathrm{N}$ sediment received by the forest ecosystem, and also necessary for understanding the feedback mechanism of the forest ecosystem for atmospheric N sediment (Thimonier, 1998).

Rainwater penetration has strong spatial heterogeneity and will be influenced by various factors such as the altitude, landform, vegetation type and edge effect (Du et al., 2008; Parker et al., 2009; Schmidt et al., 2010). The conventional rainwater collection method used to observe the $\mathrm{N}$ sediment flux is labor intensive and largely limited by the sampling point distribution. The functional group of the ion-exchange resin (IER) can dissociate some cations or anions, while absorbing other original cations or anions in the solution, so the $\mathrm{NO}_{3}{ }^{-}$in the rainwater can be fixed on functional groups that have positive charges in the resin, and $\mathrm{NH}_{4}{ }^{+}$can be fixed on functional groups that have negative charges in the resin, which keeps them more stable. With this approach, there 
will be no need for rainwater collection. Instead, regularly replacing the IER will be enough to obtain the atmospheric $\mathrm{N}$ sediment. The IER method has been widely used globally to monitor rainwater N sediment (Simkin et al., 2004; Klopatek et al., 2006; Verburg et al., 2009).

Currently in China, anion exchange resins are widely used in the $\mathrm{N}$ cycle to measure soil N (Bo et al., 2001; Fang et al., 2004; Yang et al., 2005; Li, 2005). Wang et al. (2010) used the IER method to monitor the sediment of ammonium $\mathrm{N}$ and nitrate $\mathrm{N}$ in the different functional zones in Changchun. Wenping et al. (2010) focused on the manmade ecological forest in Qianyanzhou, compared the IER method and the conventional rainwater collection method, and determined the dynamic difference of $\mathrm{N}$ sediment in forest penetrated rainwater.

Due to a high average altitude of over 4000 meters, challenging transportation and working conditions, situ data from Tibet Plateau have been scarce. This study intended to establish the linear regression equation between the conventional and the IER methods for experimental data. The IER method is more suitable for collection in remote areas or in winter as the sampling is easier and less frequent.

This study took the Picea abies forest as the research object, used the conventional rainwater collection method and the IER method at the same time to monitor the change of rainwater $\mathrm{N}$ in forests of different temperate zones and the main factors influencing the $\mathrm{N}$ content. By comparing the two methods, the feasibility of the IER method in analyzing wet sediment of atmospheric $\mathrm{N}$ was determined, and the applicability of the IER method to determine $\mathrm{N}$ sediment flux of forest rainwater in Tibet Plateau was discussed.

\section{Materials and methods}

\section{Overview of the studied area}

The experimental plot of this study is located in the standard woodland $\left(29^{\circ} 46^{\prime} \mathrm{N}, 9^{\circ} 44^{\prime} \mathrm{E}\right)$ of the South-East Tibetan Plateau Station for integrated observation and research of alpine environment of Chinese Academy of Sciences near Lulang town, Nyingchi district, Tibet Autonomous Region, which is flat and 3200 meters above sea level. Nyingchi district has the typical tropical humid and semi-humid climate that is affected by warm currents of the Indian Ocean and the Pacific Ocean. Dry and windy in spring, cool and foggy in autumn, it has a warm short summer and a sunny, cold, and long winter, and features a short frost-free period (about 170 days throughout the year) and a long frozen period. The average annual temperature is $7-16^{\circ} \mathrm{C}$; the annual average rainfall ranges from 600 to $800 \mathrm{~mm}$, and the $92.4 \%$ of the rainfall concentrates during the growing season.

In the studied area, the vegetation type is coniferous Picea abies forest in Tibetan Plateau, forest type is mature virgin forest, dominant tree species have more than 100 years of average age, the main tree species include: Abies georgei var. smithii, Picea likiangenses var. linzhiensis, Pinus yunnanensis and Pinus densata. The soil in this area is dark brown forest soil.

\section{Sample collection and analysis}

Rainwater samples were collected with self-made rain collectors, which consist of a funnel and a collecting bottle. 16 collectors were evenly placed around the experimental 
area, and 2-3 times of irregular sampling monthly were performed from May to October in 2012 (a total of 8 times of sampling in the year) based on the change of seasonal rainfall intensity. In addition, a resin bag was placed beside each rainwater collector (a nylon bag, which contains $20 \mathrm{~g}$ of anion and cation resin, respectively, is horizontally placed in the PVC tube). Resin samples were taken when sampling the rainwater. The atmospheric $\mathrm{N}$ sediment content in two samples were then determined respectively.

This study chose the anion exchange resin 717 and the cation exchange resin 732 produced by Sinopharm Chemical Reagent Co., Ltd (Shanghai). The PVC tubes beside each precipitation collector had a diameter of $7.5 \mathrm{~cm}$ and a height of $5 \mathrm{~cm}$. After each collection, new resin bags which with the same producing method would be placed in the PVC tubes to monitor the $\mathrm{N}$ content.

\section{Calculation and statistical analysis}

The $\mathrm{NH}_{4}{ }^{+}-\mathrm{N}$ and $\mathrm{NO}_{3}{ }^{-}-\mathrm{N}$ content in rainfall and resin samples can be determined using the colorimetric method (Kim, 1995).

The units of $\mathrm{N}$ sediment fluxes of different forms and resin mineral $\mathrm{N}$ flux are $\mathrm{mg} \mathrm{N} \mathrm{m}{ }^{-2}$. The average values and standard error have been calculated. The correlated coefficient of atmospheric $\mathrm{N}$ wet sediment has been regressively analyzed and calculated with the SPSS.

\section{Results}

Changes of the $N$ wet sediment flux of the coniferous Picea abies forest in Tibetan Plateau

Figure 1 shows the $\mathrm{N}$ wet sediment flux of different forms from May to October in 2012, and indicates that atmospheric $\mathrm{N}$ wet sediment flux changes with the seasons, with the highest flux in summer and low flux after the fall.

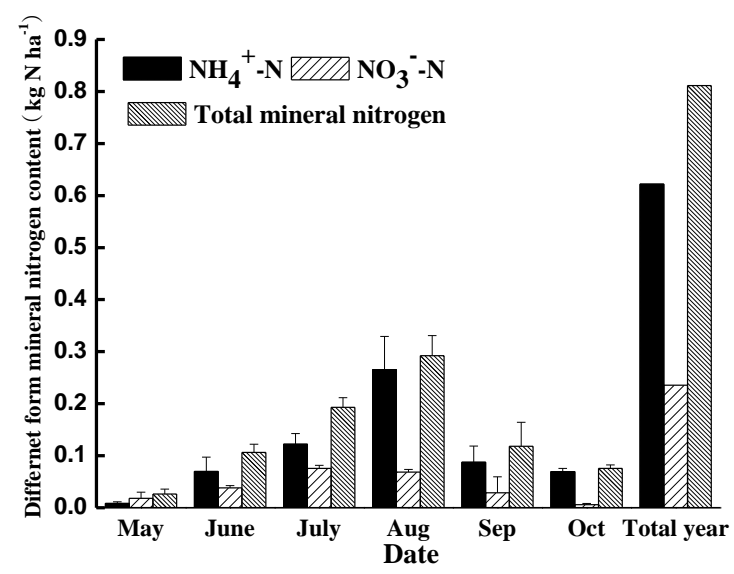

Figure 1. Seasonal change of mineral $N$ content of different forms in forest penetrated rainwater

In 2012, $\mathrm{NH}_{+}^{-}-\mathrm{N}, \mathrm{NO}_{3}{ }^{-} \mathrm{N}$ and total mineral $\mathrm{N}$ in atmospheric wet sediment amount of the coniferous Picea abies forest in Tibetan Plateau were $6.22,2.36$ and $8.58 \mathrm{~kg} \mathrm{~N}^{-}$ ${ }^{1} \mathrm{yr}^{-1}$, and ammonium $\mathrm{N}$ accounts for about $77 \%$ of the mineral N. A significant positive 
correlation has been found between the $\mathrm{NH}_{4}{ }^{-}-\mathrm{N}\left(\mathrm{y}_{1}\right)$ and $\mathrm{NO}_{3}{ }^{-} \mathrm{N}\left(\mathrm{y}_{2}\right)$ mineral $\mathrm{N}$ sediment in rainfall and the monthly average temperature $\left({ }^{\circ} \mathrm{C}\right)(\mathrm{x}$, unit: $\mathrm{mm}), \mathrm{y}_{1}=0.02 \mathrm{x}$ $0.12\left(\mathrm{R}^{2}=0.41, \mathrm{n}=6, P<0.01\right), \mathrm{y}_{2}=0.01 \mathrm{x}-0.06\left(\mathrm{R}^{2}=0.73, \mathrm{n}=6, P<0.01\right)$, and between $\mathrm{NO}_{3}{ }^{-} \mathrm{N}$ (y2) and the monthly average rainfall (x, unit: $\left.\mathrm{mm}\right), \mathrm{y}_{2}=0.0006 \mathrm{x}-$ $0.0023\left(\mathrm{R}^{2}=0.5, \mathrm{n}=6, P<0.01\right)$. However, the correlation is weaker between $\mathrm{NH}_{+}{ }^{-}-\mathrm{N}$ and the monthly rainfall $\left(\mathrm{R}^{2}=0.08\right)$.

\section{Comparison between the IER method and the conventional rainwater collection method}

The purpose of this study is to compare the IER method and the conventional rainwater collection method in determining mineral $\mathrm{N}$ wet sediment flux in the woodland. Depending on the result, the IER method may be considered for use in uninhabited areas in winter (for example, the Tibetan Plateau woodlands) instead of the conventional rainwater collection method.

From Figure 2 and Figure 3, a relatively strong correlation can be observed between the IER method and the conventional method for determining mineral nitrogen in wet sediment flux in the coniferous Picea abies forest $\left(\mathrm{R}^{2} \geq 0.46, P<0.001\right)$, but the NH4+$\mathrm{N}$ measured using the IER method is generally lower, while the $\mathrm{NO}_{3}{ }^{-}-\mathrm{N}$ is generally higher. The total mineral $\mathrm{N}$ deposition in through fall measured with both methods is about the same (Figure 3).
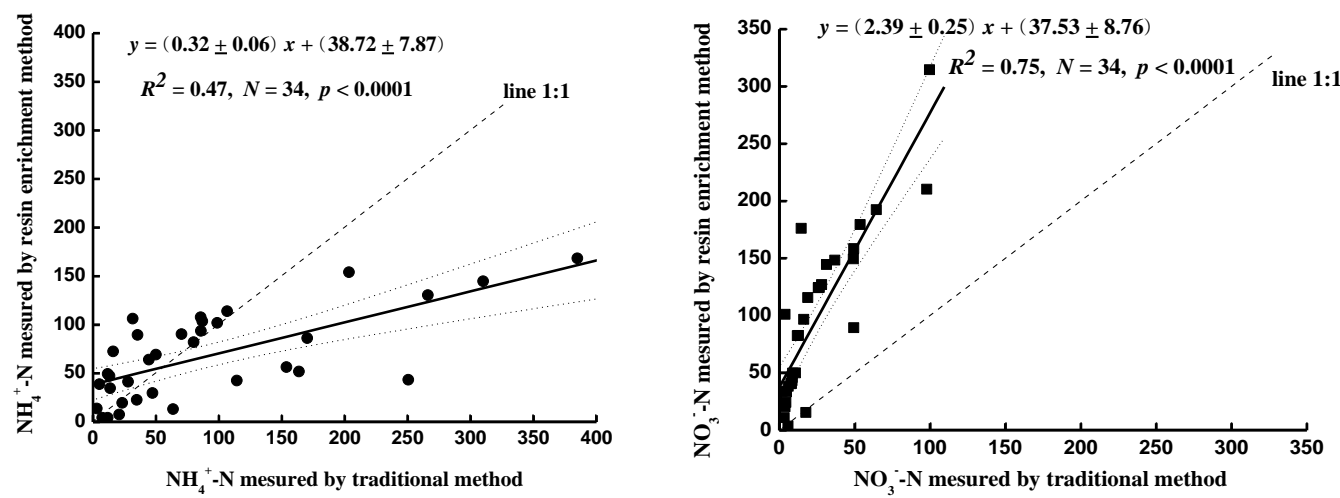

Figure 2. Comparison between the IER method and the conventional rainwater collection method in determining $\mathrm{NH}_{+}^{-}-\mathrm{N}$ and $\mathrm{NO}_{3}^{-} \mathrm{N}$ in wet sediment flux. The dotted line is $95 \%$ of upper

\section{Discussion}

\section{$N$ deposition flux characteristics and influencing factors}

The $\mathrm{N}$ sediment flux was higher in late summer and early autumn and began to decline in autumn and winter in southern China (Jianfen et al., 2005; Du et al., 2008). March, in particular, witnesses larger $\mathrm{N}$ sediment, in which $\mathrm{NH}_{4}{ }^{+}-\mathrm{N}$ takes up $64.6 \%$ of the mineral $\mathrm{N}$ sediment (Du et al., 2008). Results of this study are similar with that of Berger et al. (2008). Berger et al. (2008) measured the mineral $\mathrm{N}$ wet sediment in an Australian forest, which was lower than the mineral $\mathrm{N}$ wet sediment of forests in Germany and southern China. 
Berger et al. (2008) measured that mineral $\mathrm{N}$ wet sediment of the conifer and broadleaf forest in central Australian was 9.1-16.6 kg N ha-1 $\mathrm{yr}^{-1}$, and the sediment amount was mainly influenced by rainfall. Stephan (2001) observed obvious seasonal changes of soluble organic $\mathrm{N}$ sediment contained in the rainwater of forests in southern Germany, and found a significantly positive correlation between the soluble organic $\mathrm{N}$ and the temperature $\left(\mathrm{R}^{2}=0.58\right)$. Fang et al. (2004) also found a significantly positive correlation between the atmospheric $\mathrm{N}$ deposition and the annual precipitation, when measuring the $\mathrm{N}$ deposition in through fall in 14 forests in southern China using the IER method $\left(\mathrm{R}^{2}=0.49\right)$.

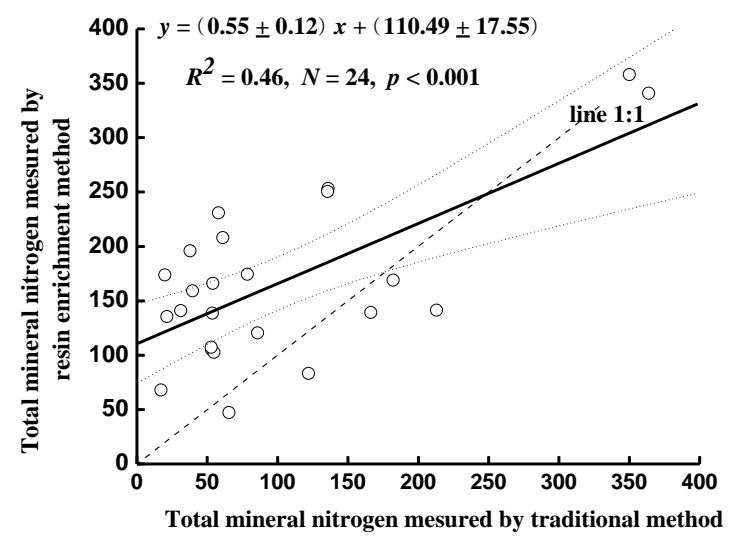

Figure 3. Comparison between the IER method and the conventional rainwater collection method in determining total mineral $N$ in wet sediment flux. The dotted line is $95 \%$ of upper

\section{Differences of results and applicability of the IER method and the rainwater collection method}

The line 1:1 in Figures 2 and 3 shows that the $\mathrm{NO}_{3}{ }^{-} \mathrm{N}$ content measured with the IER method is generally higher, and the possible reason might be that the conventional method collects samples 2-3 times a month according to the intensity of rainfall, while the IER method collects only 1 to 2 times a month. During the long sampling period, ammonium $\mathrm{N}$ converts into nitrate $\mathrm{N}$, leading to a higher nitrate $\mathrm{N}$ value in the IER method (Xu et al., 2009). However, the $\mathrm{NH}_{4}{ }^{+}-\mathrm{N}$ content measured with the IER method is generally lower, because the current speed might be too fast in ion resin column with high precipitation intensity, which does not allow for complete exchange between the ammonium $\mathrm{N}$ and the ion resin (Wenping et al., 2010). In addition, with the increase of rainfall, the atmospheric $\mathrm{N}$ deposition increases (Berger et al., 2008).

Wenping et al. (2010) also found that the mineral $\mathrm{N}$ deposition measured with the conventional method is higher in the coniferous forest. This may be caused by the conversion of the organic $\mathrm{N}$ into mineral $\mathrm{N}$ facilitated by microbes during the longer sampling time with higher precipitation intensity. Fang's research (Fang et al., 2004) results show that due to reduced precipitation in winter (October to February), the dry deposition of atmospheric $\mathrm{N}$ on the canopy would increase, and then fall down to the ground in wet sedimentation due to spring rain, which explains why the $\mathrm{N}$ content is significantly higher after the first rain of spring than other seasons. 
In addition, previous studies seldom considered the living environment outside the forest or collect resin samples monthly. However, sufficient lighting and evaporation for resin surface may lead to underestimated $\mathrm{N}$ sediment when using the IER method.

Therefore, in an uninhabited area (such as the Tibet Plateau), the IER method may be used, instead of the conventional method, in the forest zone and the growing season to determine the $\mathrm{N}$ sediment flux in atmosphere, while in the living environment outside the forest or in winter, the sampling frequency of the IER method may be increased to monthly or half-monthly.

\section{Conclusions}

A strong correlation has been found between the IER method and the conventional rainwater collection method in determining the $\mathrm{NH}_{4}{ }^{+}-\mathrm{N}$ and $\mathrm{NO}_{3}{ }^{-}-\mathrm{N}$ content $\left(\mathrm{R}^{2}=0.47\right.$ and $\left.\mathrm{R}^{2}=0.75, P<0.001\right)$. However, the $\mathrm{NH}_{4}{ }^{+}-\mathrm{N}$ content measured with the IER method is generally lower, while the $\mathrm{NO}_{3}{ }^{-} \mathrm{N}$ is generally higher. The total mineral $\mathrm{N}$ deposition in through fall measured with both methods is about the same. Therefore, we can use the IER method instead of the conventional method for determining the total inorganic $\mathrm{N}$ deposition in forest at the Tibet Plateau.

There is a correlation between atmospheric nitrogen deposition, soil nitrogen transformation, and nitrogen leaching. Atmospheric nitrogen deposition can also influence the mineralization and nitrification rate of forest soil nitrogen which can lead to woodland nitrogen loss and nitrogen storage change. China is the third largest nitrogen deposition concentration area in the world. But there is a lack of research on comprehensive assessment of the effects of deposition of different forms of nitrogen, different forest types, and different climatic factors on net mineralization flux of soil nitrogen.

Acknowledgements. This research was financially supported by Dr. Yongjie Wang, Boqing Xu and Jinlong Chang of the Southeast Mountain Environment Comprehensive observation station of Chinese Academy of Sciences assisted with sample collection and analysis. Thanks also to employees of the Institute of Tibetan Plateau Research Chinese Academy of Sciences for assistance and cooperation in the experiments. This research was supported by the National Natural Science Foundation of China (41105101 and 41405043).

\section{REFERENCES}

[1] Berger, T. W., Untersteiner, H., Schume, H., Jost, G. (2008): Through fall fluxes in a secondary spruce (Picea abies), a beech (Fagus sylvatica) and a mixed spruce-beech stand. - J. Forest Ecology and Management 255: 605-618.

[2] Bo, S., Han, X., Qu, C., Huang, J. (2001): Net nitrogen mineralization and nitrification in one pure fine (Pinus tabulaeformis) forest and one pine-oak mixed forest in Dongling Mountainous region. - J. Acta Phytoecologica Sinica 25(2): 195-203.

[3] Carly-Moses, D. E. (2004): Through fall, stem flow, and canopy interception loss fluxes in a semiarid Sierra Madre Oriental matorral community. - J. Journal of Arid Environments 58(2): 182-202.

[4] Chen, X. Y., Jan, M. (2007): Indicators for nitrogen status and leaching in subtropical forest ecosystems, South China. - J. Biogeochemistry 82: 165-180. 
[5] Du, C., Zeng, G., Zhang, G., Tang, L., Li, X., Huang, D., Huang, L., Jiang, Y. (2008): Input-output budgets for inorganic nitrogen under acid rain in a subtropical evergreen mixed forest in central-south China. - J. Water, Air \& Soil pollution 1(4): 171-181.

[6] Fang, Y. T., Mo, J. M., Gundersen, P., Zhou, G. Y., Li, D. J. (2004): Nitrogen transformations in forest soils and its responses to atmospheric nitrogen deposition: a review. - J. Acta Ecologica Sinica 24(7): 1523-1531.

[7] Glatzel, S., Stahr, K. (2001): Methane and nitrous oxide exchange in differently fertilised grassland in southern Germany. - J. Plant and soil 231(1): 21-35.

[8] Jianfen, G., Yusheng, Y., Guangshui, C., Peng, L. (2005): Dissolved organic carbon and nitrogen in precipitation, through fall and stem flow from Schima superba and Cunninghamia lanceolata plantations in subtropical China. - J. Journal of Forestry Research 16: 19-22.

[9] Kim, H. T. (1995): Soil Sampling, Preparation and Analysis. - M. New York: Marcel Dekker.

[10] Klopatek, J. M., Barry, M. J., Johnson, D. W. (2006): Potential canopy interception of nitrogen in the Pacific Northwest, USA. - J. Forest Ecology and Management 234: 344354.

[11] Li, M. R., Sha, L. Q. (2005): Soil nitrogen mineralization under different land use patterns in Xishuangbanna. - J. Chinese Journal of Applied Ecology 16(1): 54-58.

[12] Parker, B. R., Schindler, D. W., Beaty, K. G., Stainton, M. P., Kasian, S. E. M. (2009): Long-term change in climate, stream flow, and nutrient budgets for first-order catchment at the experimental Lake Area (Ontario, Canada). - J. Canadian Journal of Fisheries \& Aquatic Sciences 66: 1848-1863.

[13] Schmidt, B. H. M., Wang, C. P., Chang, S. C., Matzner, E. (2010): High precipitation causes large fluxes of dissolved organic carbon and nitrogen in a subtropical montane Chamaecyparis forest in Taiwan. - J. Biogeochemistry 101: 243-256.

[14] Simkin, S. M., Lewis, D. N., Weathers, K. C., Lovett, G. M., Schwarz, K. (2004): Determination of sulfate, nitrate, and chloride in through fall using Ion-exchange resins. J. Water, Air, and Soil Pollution 153: 343-354.

[15] Thimonier, A. (1998): Measurement of atmospheric deposition under forest canopies: Some recommendation for equipment and sampling design. - J. Environmentental Monitoring and Assessment 52(3): 353-387.

[16] Verburg, P. S. J., Johnson, D. W., Schorran, D. E., Wallace, L. L., Luo, Y., Arnone, J. A. I. (2009): Impacts of an anomalously warm year on soil nitrogen availability in experimentally manipulated intact tall grass prairie ecosystems. - J. Global Change Biology 15: 888-900.

[17] Wang, D. X., Zhao, P. S., Zhang, Y. X. (2010): Monitoring atmospheric nitrogen deposition in Changchun using ion exchange resin columns method. - J. Research of Environmental Sciences 23(8): 1013-1018.

[18] Wenping, S., Guirui, Y., Huajun, F., Yunfen, L. (2010): Determination of nitrogen deposition in through fall using ion-exchange resins: A field test in planted coniferous forest ecosystem at Qianyanzhou. - Acta Ecologica Sinica 30(24): 6872-6880.

[19] Xu, X., Han, L., Luo, X., Liu, Z., Han, S. (2009): Effects of nitrogen addition on dissolved $\mathrm{N}_{2} \mathrm{O}$ and $\mathrm{CO}_{2}$, dissolved organic matter, and inorganic nitrogen in soil solution under a temperate old-growth forest. - J. Geoderma 151(3-4): 370-377.

[20] Yang, X., Dong, Y., Yuchun, Q. I., Geng, Y., Liu, L. (2005): Soil net nitrogen mineralization in an aneulolepidium chinensisi grassland, inner Mongolia. - J. Progress in geography 24(2): 30-37. 